\title{
The Figurative Meaning Of Metaphorical Expression In "Raja Ampat" Article On Indonesia,Travel Website
}

\author{
Zefta Marcell Wijanarto $^{1}$ \\ ${ }^{1}$ Universitas Sanata Dharma \\ Marcell.zefta@gmail.com ${ }^{1}$
}

\begin{abstract}
Tourism is an essential element of modern life and modern society. Easy access to the internet facilitates the promotion of tourism spreading across the world. Through Indonesia.travel, the Ministry of Tourism of Indonesia official provides information about Indonesia tourism and travel. Raja Ampat, famous for its underwater destination, is one of the travel destinations highlighted on the website. Metaphorical expression frequently appears to describe Raja Ampat destination. This research focuses on observing how the language, specifically metaphor, is used in an article in Indonesia.travel entitled "Raja Ampat" to represent the nature of Raja Ampat as the travel destination. This study seeks to contribute to a better understanding of the role of metaphors in the mechanics of persuasion in promotional tourism discourse with a different approach, which is a semantic approach. The analysis metaphorical expressions to reveal the domains of tourism destination highlighted in the text are expected to shed light on how linguistics is closely related to various persuasion functions used in promotional tourism discourse. 13 metaphorical expressions found in the article. Source domain Building, Natural Landscape, High-Mobility, Religion, Family, Profession is utilized in metaphorical expression. It signifies that metaphor is used as a tool to bring the destination closer to travelers living in a city-situated environment.
\end{abstract}

Keywords : tourism, semantics, metaphor

\begin{abstract}
Abstrak
Pariwisata merupakan elemen penting dari kehidupan modern dan masyarakat modern. Akses mudah ke internet memfasilitasi promosi pariwisata yang menyebar ke seluruh dunia. Melalui Indonesia.travel, Kementerian Pariwisata RI secara resmi memberikan informasi seputar pariwisata dan travel Indonesia. Raja Ampat yang terkenal dengan destinasi bawah lautnya merupakan salah satu destinasi wisata yang disorot di website. Ungkapan metaforis sering muncul untuk menggambarkan tujuan Raja Ampat. Fokus penelitian ini adalah mengamati bagaimana bahasa, khususnya metafora, digunakan dalam sebuah artikel di Indonesia.travel bertajuk "Raja Ampat" untuk merepresentasikan sifat Raja Ampat sebagai tujuan wisata. Penelitian ini berupaya untuk memberikan kontribusi pemahaman yang lebih baik tentang peran metafora dalam mekanisme persuasi dalam wacana promosi pariwisata dengan pendekatan berbeda, yaitu pendekatan semantik. Analisis ekspresi metaforis untuk mengungkap domain tujuan wisata yang disoroti dalam teks diharapkan dapat menjelaskan bagaimana linguistik terkait erat dengan berbagai fungsi persuasi yang digunakan dalam wacana promosi pariwisata. 13 ekspresi metaforis ditemukan dalam artikel. Bangunan Domain Sumber, Bangunan Alam, Mobilitas Tinggi, Agama, Keluarga, Profesi digunakan
\end{abstract}


dalam ekspresi metaforis. Ini menandakan bahwa metafora digunakan sebagai alat untuk mendekatkan tujuan kepada pelancong yang tinggal di lingkungan yang terletak di kota.

Kata kunci: pariwisata, semantik, metafora.

\section{Introduction}

Tourism is a pervasive phenomenon of modern life and modern society. Jaworski and Pritchard (2005) explain that it has become important in a social process of change in which human systems, values and communities are being integrated in a move towards global social and economic networks. Furthermore, the straightforward access of internet facilitates them in communication. Therefore, they have easy access to get any information and share information around the world. A lot of travel marketers, as a result, take advantage by promoting their tourism and travel on the internet, which serves as a digital promotion media, including the Ministry of Tourism of Indonesia.

The Ministry of Tourism of Indonesia official provides information about Indonesia tourism and travel on a website, namely Indonesia.travel. It can be accessed on www.Indonesia.travel. One of the destinations highlighted on the website is Raja Ampat, which is famous for its coastal sites. Moreover, Valentina (2016) mentions that Raja Ampat has been recognized at the Global Green Destinations Day event as Top 100 Global Destinations. Its natural beauty, of course, becomes the attention of the government of Indonesia, and that must be the reason why it is put on the highlight. Yet, tourism is not only about promotion. It is a way to create a positive national identity for foreign consumption so that foreign investment and support development can be gained (Salim, Ibrahim, \& Hassan, 2012, p. 140). Therefore, to describe tourism destination, the language used on the website often promotes what travel events and experiences tourists may enjoy. At the same time, the advertiser also faces the challenge of forming tourism images. Hence, the advertiser highlights to be more creative in choosing the preference of techniques and tools to influence consumers' minds. In this situation, figurative language consequently appears on frequent time in the language used on the website. 


\section{Jurnal DinamikA}

Volume 1 No. 2 (2020)

E-ISSN: 2723-1410

Website: https://jurnal.iainsalatiga.ac.id/index.php/dinamika/index

The use of figurative language is an essential element on the tourism website. Phillips and McQuarrie (2004) agree that consumers are more favorable to the use of figures of speech, as it helps them visualize intangible items. One of the main reasons for the use of figurative language, according to Jaworska (2017), is its ability to reduce what-so-called the effect of strangeness by turning an unfamiliar phenomenon into something familiar and recognizable.

Metaphor is one of figurative languages used mainly to cope with the unfamiliarity of a destination for the tourist. Djavarova (2017) explains that the reader reacts to the text, which is relevant to the individual, to the text where information about the place or service looks familiar. Thus, one particular role of the metaphor is to reduce the effect of unfamiliarity. (p. 40). When metaphor is used in the text, it automatically directs the customer to look at the product from a different point of view (Palmer and Lundberg, 1995). Young (2000) in (Jaworska, 2017) believes that it makes a reader consider new associations by drawing links between the source domain object of the metaphor. The function of metaphor can be illustrated by the sentence "Raja Ampat is a paradise." As the person reads the sentence, the reader is forced directly to draw a link between two objects. It forces them to make an association between "Raja Ampat" and "paradise." The use of metaphor allows the readers to look at the described image from a different point of view as the aim is to attract attention of the customer and sell the product, positive features are expected to be emphasized in this context (Paivio and Clarke, 1986).

The related studies focusing on observing the use of metaphor in promotional tourism discourse has been done beforehand with different approaches. Using corpus-assisted approach, Jaworska (2017) found out that domains such as body, natural precious element, colour, taste, and religion on the metaphorical expression point to a significant use in the descriptions of tropical destinations. Applying pragmatic approach, Djafarova and Anderson (2008) concluded that a decrease in the amount of advertisements using metaphors over the time period investigated since consumers are increasingly likely to complain about misleading advertising. Utilizing Critical Discourse Analysis approach, Ágnes (2009) criticized 
that the concept of interpersonal relationship health and beauty among the society were constructed by the marketers using metaphors.

This present research, triggered by the above-mentioned studies, takes similar data, which is text on tourism website. It focuses on how the language, specifically metaphor, is used in an article in Indonesia.travel entitled "Raja Ampat" to represent the nature of Raja Ampat as the travel destination. This study seeks to contribute to a better understanding of the role of metaphors in the mechanics of persuasion in promotional tourism discourse with a different approach, which is a semantic approach. The analysis of metaphorical expressions to reveal the domains of tourism destination highlighted in the text is expected to shed light on how linguistics is closely related to various persuasion functions used in promotional tourism discourse. Furthermore, limited research is undertaken to understand the way the language is used in tourism (Djafarova and Andersen, 2008; Dann, 1996). The majority of tourism research explores the images represented visually (Urry, 1990; Gonzalez and Bello, 2002). Little attention is paid to verbal expression, while it also has an important visual element (Williamson, 1978). Therefore, it becomes the reason why the writer aims to contribute more in analyzing the use and the function of metaphors in the domain of tourism promotional discourse.

\section{Methodology}

The metaphorical expressions found in the text of Raja Ampat article, that takes place on one spot in Destination Highlights on the front page of the website, were taken from Indonesia.travel, the official website of Indonesia tourism accessed at www.indonesia.travel on October 1, 2020. To the identification of metaphorical expressions, the researcher utilized Metaphor Identification Procedure (MIP) developed by the Pragglejaz (2007). In detail, MIP is formulated as follows: firstly, the researcher red the discourse thoroughly to build public understanding of its meaning. Secondly, the researcher specified the lexical unit in the discourse. Thirdly, (a) For each lexical unit in the text, the researcher saw its meaning in the context of i.e. How do the meanings it applies, as an entity, attribute, or relation in the situation posed by the text (contextual meaning)? The researcher estimated what comes before and 


\section{Jurnal DinamikA}

Volume 1 No. 2 (2020)

E-ISSN: $2723-1410$

Website: https://jurnal.iainsalatiga.ac.id/index.php/dinamika/index

after the lexical units. (b) For each lexical unit, the researcher determined whether the unit has a contemporary meaning more basic in other contexts than in the context. In this metaphor, the identification of the basic meanings tends to be: (i) more real (what is expressed more easily imaginable, views, be heard, touched, kissed, and perceived); (ii) related to the physical act; (iii) more precise (not vague); and (iv) are historically older. The meaning of the basis must be such meaning often arises the most from the lexical units. (c) if the lexical units have contemporary significance more basic in another context compared to the existing context, the researcher checked whether the meaning of the basic meaning is different from the contextual but can be understood through the comparison with the basic meaning. Lastly, if yes, the researcher marked the lexical unit as a metaphor (Pragglejaz, 2007 p. 5 - 6). In conducting this study, this study applies semantic approach. Semantics is the study of the linguistic meaning of morphemes, words, phrases, and sentences (Fromkin, Rodman, \& Hyams, 2011, p. 140). Since to figure out how metaphorical expressions used in "Raja Ampat" article by defining their literal meaning and figurative meaning, and to determine the domain highlighted from metaphorical expressions is the main focus of this study, hence semantic is the most suitable approach. It happens for it is the study of meaning of words and phrases. The use of words or phrases in metaphorical expressions contribute to form meaning intended.

In conducting this study, the researcher took three steps. Firstly, a list of metaphorical expressions was made based on Metaphor Identification Procedure (MIP). Accordingly, the data were segmented into lexical units and phrasal verbs marked as single segments. However, in the high number of cases metaphorical expressions appeared across longer chains of units, which frequently combined distinct metaphors or metaphors with alliterations, personifications and also hyperbole. For instance, the phrase 'a busy colleague, the turtle' has two items' colleague' and 'busy' were recognized as being non-literal with personified 'busy' emphasizing the metaphorical meaning of 'a colleague, the turtle'. Secondly, the figurative meaning of metaphorical expressions was assigned based on the comparison between the contextual meaning of the item and its literal meaning as 
defined in Lexico Dictionary online powered by Oxford, accessed on www.lexico.com. The application of semantic property is to compare literal meaning and to examine the exact meaning of metaphor. Lastly, all metaphorical expressions found on the text were manually tagged for source domains suitable to their literal meaning(s).

\section{Findings and Discussion}

This section provides the analysis of the data examining the figurative meaning and the domain of metaphorical expressions. The researcher finds out 12 metaphorical expressions and 12 domains of metaphorical expressions from "Raja Ampat" article.

The observation of the text on "Raja Ampat" article distinguishes certain function of metaphor. Creating awareness is one of them. Promoting 'untouched' destinations which are unfamiliar to tourists, travel marketers aims to decrease the level of the strangeness factor and attach some recognizable features, which visualize the images in traveler's minds. In this discussion, the meaning of words for instance' home,' 'library,' 'school,' 'colleague,' 'assistant,' etcetera, that are found on metaphorical expressions used on the website undergo a shift in meaning from their dictionary meaning due to promotion purpose. The following discussion provides the dictionary meaning and figurative meaning regarding to the context.

\section{Figurative Meaning of Metaphorical Expressions}

"Far from the view-blocking skyscrapers, dense and hectic concrete jungles" is metaphorical expression occurred on the article. In the text, travel marketer gives a narration that the tourism destination offered in Raja Ampat provides a natural green forest and blue sea water atmosphere that a city consisting a significant number of large modern buildings do not have. Through the use of this metaphorical expression, the readers are forced to draw a link between 'concrete,' that is in Lexico Dictionary Online is described as 'existing in a material or physical form' and 'jungle' described as 'an area of land overgrown with dense forest and tangled vegetation, typically in the tropics,' so that it visualizes concrete object like stones existing all over 


\section{Jurnal DinamikA}

Volume 1 No. 2 (2020)

E-ISSN: 2723-1410

Website: https://jurnal.iainsalatiga.ac.id/index.php/dinamika/index

the place creating unpleasant atmosphere. Moreover, Oxford Learner's Dictionary asserts that the phrase 'concrete jungle' means 'a way of describing a city or an area that is unpleasant because it has many large modern buildings and few trees or parks.' It is considered as an example of dead metaphor, which according to (Newmark, 1988, p. 106), is the metaphor that becomes a normal language since people are not recognizing it as metaphor and people always use it in everyday life so that it becomes daily language. Therefore, the dictionary includes this phrase into it. By mentioning this metaphorical expression, travel marketer seemingly tries to give a portrayal of a metropolitan city, and in doing so, it targets the tourists who live in the city to visit Raja Ampat.

Table 1. Figurative Meaning of 'concrete jungles'

\begin{tabular}{|l|l|}
\hline $\begin{array}{l}\text { Metaphorical } \\
\text { Expression }\end{array}$ & concrete jungles \\
\hline Literal Meaning & $\begin{array}{l}\text { an area of land overgrown with dense forest and tangled } \\
\text { vegetation made from concrete material }\end{array}$ \\
\hline $\begin{array}{l}\text { Metaphorical } \\
\text { Meaning }\end{array}$ & $\begin{array}{l}\text { a city or an area that is unpleasant because it has many } \\
\text { large modern buildings }\end{array}$ \\
\hline Semantic Property & (+landscape) \\
\hline
\end{tabular}

"you will find a pristine paradise... ." is the next metaphorical expression appeared on the article. In this text, the meaning of 'paradise' differs to 'heaven as the ultimate abode of the just' as mentioned in Lexico Dictionary Online. 'Pristine paradise' refers to Raja Ampat since "Raja Ampat" article informs the reader about Raja Ampat as travel destination. This metaphorical expression is an example of original metaphor. The advertisers utilize their own phrases to deliver a message and put some irrational expression to the text describing their imagination. They change the words or phrases that were often used by people into different words or phrases, to make the text more complex or interesting (Newmark, 1988, p. 112). On the article, the writer intends that 'paradise' is a word used to give the readers a picture 
of Raja Ampat. Moreover, the word 'pristine' which is explained by Lexico Dictionary Online as 'in its original condition; unspoilt' emphasizes that the figurative meaning of 'pristine paradise' is an extremely beautiful destination, Raja Ampat, that seems perfect and that travelers rarely visit. As 'pristine paradise' in the text is associated with the Raja Ampat as travel destination, travel marketer tries to give the tourist the images of Raja Ampat portrayed perfect as in imagination in each tourist's mind.

Table 2. Figurative Meaning of 'a pristine paradise'

\begin{tabular}{|l|l|}
\hline $\begin{array}{l}\text { Metaphorical } \\
\text { Expression }\end{array}$ & a pristine paradise \\
\hline Literal Meaning & heaven as the ultimate abode of the just \\
\hline $\begin{array}{l}\text { Metaphorical } \\
\text { Meaning }\end{array}$ & $\begin{array}{l}\text { extremely beautiful destination that seems perfect and } \\
\text { that travelers rarely visit }\end{array}$ \\
\hline Semantic Property & (+target) \\
\hline
\end{tabular}

"... Mother Nature and warm friendly people welcome you with all the exceptional wonders in Raja Ampat, the islands-regency in West Papua Province." Metaphorical expression 'Mother Nature' is considered as dead metaphor also as described on the previous discussion. 'Mother' refers to a word with different meaning from 'a woman in relation to her child or children' as defined in Lexico Dictionary. However, it is a nature providing the natural beauty of Raja Ampat landscape. Phrase 'Mother Nature' has become daily language, so the meaning on Lexico Dictionary, 'Nature personified as a creative and controlling force affecting the world and humans' has represented its figurative meaning. It is asserted by Urban Dictionary that describes it as 'a term used to personify nature.' Furthermore, 'mother' according to Urban Dictionary is 'the best person on earth because she raised you to be who you are and probably loves you no matter what.' The application of this metaphorical expression increases the sense of belonging and the sense of coming home. It is what travel marketer would like to achieve.

Table 3. Figurative Meaning of 'Mother Nature' 
Jurnal DinamikA

Volume 1 No. 2 (2020)

E-ISSN: 2723-1410

Website: https://jurnal.iainsalatiga.ac.id/index.php/dinamika/index

\begin{tabular}{|l|l|}
\hline $\begin{array}{l}\text { Metaphorical } \\
\text { Expression }\end{array}$ & Mother Nature \\
\hline Literal Meaning & $\begin{array}{l}\text { Nature personified as a creative and controlling force } \\
\text { affecting the world and humans }\end{array}$ \\
\hline $\begin{array}{l}\text { Metaphorical } \\
\text { Meaning }\end{array}$ & $\begin{array}{l}\text { Nature, considered as the source and guiding force of } \\
\text { creation, that provides pleasant atmosphere for its beauty }\end{array}$ \\
\hline Semantic Property & (+landscape) \\
\hline
\end{tabular}

"... home to 540 types of corals." In Lexico Dictionary Online, 'home' refers to 'house or flat.' However, in this metaphorical, 'home' refers to the natural habitat of underwater biota since corals are the ones that live in that place. Travel marketer uses 'home' to emphasize atmosphere of feeling home as described in Urban Dictionary 'a feeling so comfortable somewhere or someone you can always go to go back to.' As 'home' is used to describe the natural habitat of underwater biota, travel marketer intends that Raja Ampat offers the travelers a glance of underwater scenery where they could meet their another family, which are underwater biotas swimming over the corals.

Table 4. Figurative Meaning of 'home'

\begin{tabular}{|l|l|}
\hline $\begin{array}{l}\text { Metaphorical } \\
\text { Expression }\end{array}$ & Home \\
\hline Literal Meaning & $\begin{array}{l}\text { The house or flat that you live in, especially with your } \\
\text { family }\end{array}$ \\
\hline $\begin{array}{l}\text { Metaphorical } \\
\text { Meaning }\end{array}$ & $\begin{array}{l}\text { An underwater atmosphere where a plant or animal } \\
\text { usually lives peacefully }\end{array}$ \\
\hline Semantic Property & \begin{tabular}{l} 
(+protection) \\
\hline
\end{tabular} \\
\hline
\end{tabular}

"This makes it the most diverse living library for the world's coral reef and underwater biota." The text explains the world's coral reef and underwater biota scenery. In the 
metaphorical expression above, 'library' has a meaning further from the definition mentioned by Lexico Dictionary, that is 'building or room containing collections of books, periodicals, for use or borrowing by the public or the members of an institution.' Yet, it refers to underwater scenery. Urban Dictionary asserts that the definition of library is 'an awesome place that is underrated in today's society.' As a result, 'an awesome underwater scenery in which many types of coral reef and underwater biota naturally live' is suitable to define its figurative meaning. By mentioning 'library' to portray the image of coral reef and underwater biota, travel marketer emphasizes image of an awesome place with awesome variety of underwater biota.

Table 5. Figurative Meaning of 'the most diverse living library'

\begin{tabular}{|l|l|}
\hline $\begin{array}{l}\text { Metaphorical } \\
\text { Expression }\end{array}$ & the most diverse living library \\
\hline Literal Meaning & $\begin{array}{l}\text { A building or room containing the highest number of } \\
\text { collections of living creatures }\end{array}$ \\
\hline $\begin{array}{l}\text { Metaphorical } \\
\text { Meaning }\end{array}$ & $\begin{array}{l}\text { An awesome underwater scenery in which many types of } \\
\text { coral reef and underwater biota naturally live }\end{array}$ \\
\hline Semantic Property & (+variety) \\
\hline
\end{tabular}

"Schools of Tuna fish, giant trevallies, snappers, batfish, and even barracudas are there to complete your underwater "meeting list."' The text above pictures fishes appearing in Raja Ampat underwater. The definition of 'school' stated by Lexico Dictionary emphasizes on 'institution for educating children.' However, this metaphorical expression is associated to underwater atmosphere where fishes swimming around. It happens since the member in this 'school' consists of fishes, 'tuna fish, giant trevallies, snappers, batfish, and barracudas.' Utilizing a word 'school' in promoting tourism is a great idea. The sense of education appears to be highlighted as travelers visit the destination: Raja Ampat offers the knowledge regarding underwater biotas. This notion seemingly considered as the goal tried to achieve by travel marketer. 
Jurnal DinamikA

Volume 1 No. 2 (2020)

E-ISSN: 2723-1410

Website: https://jurnal.iainsalatiga.ac.id/index.php/dinamika/index

Table 6. Figurative Meaning of 'schools'

\begin{tabular}{|l|l|}
\hline $\begin{array}{l}\text { Metaphorical } \\
\text { Expression }\end{array}$ & Schools \\
\hline Literal Meaning & A place where fishes are educated \\
\hline $\begin{array}{l}\text { Metaphorical } \\
\text { Meaning }\end{array}$ & $\begin{array}{l}\text { An underwater atmosphere where fishes are swimming } \\
\text { around }\end{array}$ \\
\hline Semantic Property & (+experience) \\
\hline
\end{tabular}

"Schools of Tuna fish, giant trevallies, snappers, batfish, and even barracudas are there to complete your underwater "meeting list."' Lexico Dictionary describes that the meaning of 'meeting' is 'an assembly of people for a particular purpose, especially for formal discussion.' While, 'list' is defined as 'a number of connected items, written or printed consecutively, typically one below the other.' Hence the literal meaning of 'meeting list' is 'a number of connected items, written or printed consecutively, typically one below the other consisting the scheduled assembly of people for a particular purpose.' However, it has a figurative meaning. 'Meeting', mentioned in the above dictionary as 'formal discussion,' signifies another meaning since the participant of the meeting are tuna fish, giant trevallies, snappers, batfish, and even barracudas, not 'people' as mentioned in the above dictionary. Therefore, the figurative meaning of 'meeting list' refers to underwater activity such as snorkeling, diving, and swimming. In doing so, travel marketer seemingly offers traveler to enjoy several underwater activities provided in Raja Ampat.

Table 7. Figurative Meaning of 'meeting list'

\begin{tabular}{|l|l|}
\hline $\begin{array}{l}\text { Metaphorical } \\
\text { Expression }\end{array}$ & meeting list \\
\hline Literal Meaning & $\begin{array}{l}\text { A number of connected items, written or printed } \\
\text { consecutively, typically one below the other consisting the } \\
\text { scheduled assembly of people for a particular purpose. }\end{array}$ \\
\hline
\end{tabular}




\begin{tabular}{|l|l|}
\hline $\begin{array}{l}\text { Metaphorical } \\
\text { Meaning }\end{array}$ & $\begin{array}{l}\text { Underwater trip such as snorkeling, diving, and } \\
\text { swimming }\end{array}$ \\
\hline Semantic Property & (+appointment) \\
\hline
\end{tabular}

"... not to mention the friendly assistant of the dugong, and a busy colleague, the turtle." 'Kind and pleasant' is dictionary-based meaning of 'friendly.' Then, 'person who ranks below a senior person' is the definition of 'assistant' according to Lexico Dictionary. So, the literal meaning of 'friendly assistant' is 'a kind person who ranks below a senior person.' However, in this metaphorical expression, 'friendly assistant' indicates distinct meaning. It points to the dugong, not human as described by the dictionary. Hence, 'an underwater biota swimming around accompanying the visitors, divers, or snorkelers' is suitable to describe figurative meaning of 'friendly assistant'. The word 'friendly', attached to underwater animal by travel marketer, is an interesting way to give the travelers an introduction to the nature of animal living on the Raja Ampat underwater. Moreover, 'assistant' is a profession. Travel marketer seemingly also tries to bring Raja Ampat closer to the tourists working on the company. Simply they become the target of Raja Ampat promotion.

Table 8. Figurative Meaning of 'friendly assistant'

\begin{tabular}{|l|l|}
\hline $\begin{array}{l}\text { Metaphorical } \\
\text { Expression }\end{array}$ & Friendly assistant \\
\hline Literal Meaning & A kind person who ranks below a senior person. \\
\hline $\begin{array}{l}\text { Metaphorical } \\
\text { Meaning }\end{array}$ & $\begin{array}{l}\text { An underwater biota swimming around accompanying } \\
\text { the visitors, divers, or snorkelers }\end{array}$ \\
\hline Semantic Property & (+profession) \\
\hline
\end{tabular}

"... not to mention the friendly assistant of the dugong, and a busy colleague, the turtle." 'a busy colleague' is similar to the 'friendly assistant' on the above explanation. Lexico Dictionary mentions that the meaning of busy is '(of a time or place) full of activity.' Then, 'a person with whom one works in a profession or business' is the definition 


\section{Jurnal DinamikA}

Volume 1 No. 2 (2020)

E-ISSN: $2723-1410$

Website: https://jurnal.iainsalatiga.ac.id/index.php/dinamika/index

of 'colleague' in the dictionary. 'A person, full of activity, with whom one works in a profession or business,' therefore, is the literal meaning of 'busy colleague.' Yet, 'busy colleague' has figurative meaning. It refers to the 'turtle', not 'a person' as explained in the dictionary. Hence, 'an underwater biota swimming around accompanying the visitors, divers, or snorkelers' is suitable to define 'busy colleague.' Again, travel marketer emphasizes on bringing Raja Ampat closer to consumers on the workplace since 'colleague' is corresponded to profession or business.

Table 9. Figurative Meaning of 'a busy colleague'

\begin{tabular}{|l|l|}
\hline $\begin{array}{l}\text { Metaphorical } \\
\text { Expression }\end{array}$ & a busy colleague \\
\hline Literal Meaning & $\begin{array}{l}\text { A person, full of activity, with whom one works in a } \\
\text { profession or business. }\end{array}$ \\
\hline $\begin{array}{l}\text { Metaphorical } \\
\text { Meaning }\end{array}$ & $\begin{array}{l}\text { An underwater biota swimming around accompanying } \\
\text { the visitors, divers, or snorkelers }\end{array}$ \\
\hline Semantic Property & (+profession) \\
\hline
\end{tabular}

"... the rock islets amidst the clear blue water and bright blue sky in Piaynemo offers some of the most spectacular sceneries on the face of the earth." In this metaphorical expression, 'blue' is examined as an example of dead metaphor, which according to (Newmark, 1988, p. 106), is the metaphor that becomes a normal language since people are not recognizing it as metaphor and people always use it in everyday life so that it becomes daily language. 'blue' which refers to 'water' creates a literal meaning, 'water which the colour is intermediate between green and violet, as of the sky or sea on a sunny day.' That 'blue' in 'blue water' is a metaphor to describe the water that 'seemingly between green and violet' is unrecognizable and it becomes daily language.

Table 10. Figurative Meaning of 'blue' 


\begin{tabular}{|l|l|}
\hline $\begin{array}{l}\text { Metaphorical } \\
\text { Expression }\end{array}$ & Blue \\
\hline Literal Meaning & $\begin{array}{l}\text { The colour is intermediate between green and violet, as } \\
\text { of the sky or sea on a sunny day. }\end{array}$ \\
\hline $\begin{array}{l}\text { Metaphorical } \\
\text { Meaning }\end{array}$ & that seemingly between green and violet \\
\hline Semantic Property & \begin{tabular}{l} 
(+color) \\
\hline
\end{tabular} \\
\hline
\end{tabular}

"...the most spectacular sceneries on the face of the earth." 'Face' in this metaphorical is also a dead metaphor. Lexico Dictionary defines 'face' as 'the front part of a person's head from the forehead to the chin, or the corresponding part in an animal.' However, 'face' as metaphor refers to 'surface of physical material.' Then since it becomes daily language, Oxford Learner's Dictionaries includes 'face' in the dictionary as 'a side or surface of something.' In this metaphorical expression, 'face' is used to describe Raja Ampat landscape.

Table 11. Figurative Meaning of 'face'

\begin{tabular}{|l|l|}
\hline $\begin{array}{l}\text { Metaphorical } \\
\text { Expression }\end{array}$ & Face \\
\hline Literal Meaning & $\begin{array}{l}\text { The front part of a person's head from the forehead to the } \\
\text { chin, or the corresponding part in an animal. }\end{array}$ \\
\hline $\begin{array}{l}\text { Metaphorical } \\
\text { Meaning }\end{array}$ & Earth landscape \\
\hline Semantic Property & (+landscape) \\
\hline
\end{tabular}

"Mother Nature painted her finest artwork and offers a glimpse of paradise." According to Lexico Dictionary, 'artwork' is described as 'illustrations, photographs, or other nontextual material prepared for inclusion in a publication.' However, in this metaphorical expression, it points out a further meaning. Here, 'artwork' is a product produced by the 'nature.' The word 'painted' which means 'over the surface of 


\section{Jurnal DinamikA}

Volume 1 No. 2 (2020)

E-ISSN: 2723-1410

Website: https://jurnal.iainsalatiga.ac.id/index.php/dinamika/index

(something) with paint' according to Lexico Dictionary signifies that the 'artwork' is produced by the nature. 'Artwork' in this metaphorical expression refers to Raja Ampat landscape. Hence, 'a tourism destination, full of the nature's beauty, that is extremely magnificent and that seems perfect to enjoy' is suitable as the figurative meaning of 'finest artwork'. By stating 'artwork' to represent Raja Ampat nature, travel marketer seemingly highlights that Raja Ampat offers an aesthetic experience for traveler to enjoy.

Table 12. Figurative Meaning of 'finest artwork'

\begin{tabular}{|l|l|}
\hline $\begin{array}{l}\text { Metaphorical } \\
\text { Expression }\end{array}$ & finest artwork \\
\hline Literal Meaning & $\begin{array}{l}\text { The best Illustrations, photographs, or other non-textual } \\
\text { material prepared for inclusion in a publication. }\end{array}$ \\
\hline $\begin{array}{l}\text { Metaphorical } \\
\text { Meaning }\end{array}$ & $\begin{array}{l}\text { a tourism destination, full of the nature's beauty, that is } \\
\text { extremely magnificent and that seems perfect to enjoy }\end{array}$ \\
\hline Semantic Property & (+aesthetic) \\
\hline
\end{tabular}

"Raja Ampat welcomes you to the Heaven on Earth." Lexico Dictionary mentions that the meaning of 'heaven' is a place regarded in various religions as the abode of God (or the gods) and the angels, and of the good after death, often traditionally depicted as being above the sky. However, the meaning is further than the dictionary meaning since it refers to Raja Ampat as travel destination. Urban Dictionary asserts that heaven is happiness beyond what you would ever hope to wish for. Hence, 'an extremely beautiful tourism destination in which people are very happy and everybody wants to visit' is suitable to define 'heaven' in this metaphorical expression. By mentioning 'heaven' to describe Raja Ampat, travel marketer offers travelers a perfect image of tourism destination as perfect as the imagination in travelers' minds.

Table 13. Figurative Meaning of 'heaven'

\begin{tabular}{|l|l|}
\hline Metaphorical & Heaven \\
Expression & \\
\hline
\end{tabular}




\begin{tabular}{|l|l|}
\hline Literal Meaning & $\begin{array}{l}\text { A place regarded in various religions as the abode of God } \\
\text { (or the gods) and the angels, and of the good after death, } \\
\text { often traditionally depicted as being above the sky. }\end{array}$ \\
\hline $\begin{array}{l}\text { Metaphorical } \\
\text { Meaning }\end{array}$ & $\begin{array}{l}\text { An extremely beautiful tourism destination in which } \\
\text { people are very happy and everybody wants to visit }\end{array}$ \\
\hline Semantic Property & (+target) \\
\hline
\end{tabular}

\section{Source of Domain of Metaphorical Expressions}

This following section offer qualitative insights into source domain of metaphorical expressions found in "Raja Ampat" article. The data found are presented in the table as follows.

Table 14. Source Domain of Metaphorical Expression

\begin{tabular}{|l|l|l|}
\hline Source Domain & Word & Total \\
\hline LATURAL & jungle (1) & 1 \\
\hline BUILDING & $\begin{array}{l}\text { Library (1), home (1), concrete (1), schools } \\
(1)\end{array}$ & 4 \\
\hline HIGH-MOBILITY & Busy (1) & 1 \\
\hline RELIGION & Paradise (2), heaven (1) & 3 \\
\hline HIGH-CONTRAST & Bright (1) & 1 \\
\hline WATER & Underwater (1) & 1 \\
\hline FAMILY & Mother (2) & 2 \\
\hline HIGH-QUALITY & Finest (1) & 1 \\
\hline PRODUCT & Artwork (1) & 2 \\
\hline PURITY & Pristine (1), clear (1) & 2 \\
\hline PROFESSION & Assistant (1), colleague (1) & Blue (2) \\
\hline COLOR & & 1 \\
\hline
\end{tabular}




\section{Jurnal DinamikA}

Volume 1 No. 2 (2020)

E-ISSN: $2723-1410$

Website: https://jurnal.iainsalatiga.ac.id/index.php/dinamika/index

The source domain BUILDING has the greatest number with 4 appearance. RELIGION source domain is following with 3 appearances. Then, each of source of domain COLOR, PROFESSION, PURITY, and FAMILY has 2 words appearance. Lastly, a word with source of domain HIGH-MOBILITY, PRODUCT, HIGHCONTRAST, and NATURAL LANDSCAPE appears in the metaphorical expressions.

Source domain BUILDING points to the highest significant use in the "Raja Ampat" article. As metaphor is utilized to decrease the unfamiliarity of features of the presented object, it should rationally follow that its usage tends to increase in direct relationship to the strangeness level of the travel destination being pictured. Source domain BUILDING points to a significant use since the words with its domain for instance' school,' 'library,' and 'schools' are familiar for people living in the city-related environment. Simply, travel marketer also aims to target those travelers. The use of metaphor with other domains: NATURAL LANDSCAPE, HIGH-MOBILITY, RELIGION, FAMILY, PROFESSION support the notion that metaphor is used as a tool to bring the destination closer to traveler.

\section{Conclusion}

The Ministry of Tourism of Indonesia official provides information about Indonesia tourism and travel on Indonesia.travel. 13 metaphorical expressions are found on the website. Metaphorical expressions found points to further meaning than dictionary-based meaning for the promotion goal. Source domain BUILDING, NATURAL LANDSCAPE, HIGH-MOBILITY, RELIGION, FAMILY, and PROFESSION are found in 13 metaphorical expression. It signifies the notion that metaphor is used as a tool to bring the destination closer to traveler. 


\section{References}

Bastida, U., and Huan, T. C. 2014. Performance evaluation of tourism websites' information quality of four global destination brands: Beijing, Hong Kong, Shanghai, and Taipei. Journal of Business Research. 67, 2, 167-170

Dann, G. M. S. 1996. The Language of Tourism: A Sociolinguistics Perspective. UK, CAB International.

Dann, G. M. S. 2002. The tourist as a metaphor of the social world. UK, CABI Publishing.

Dann, G. M. S. 2002. Theoretical Issues for Tourism's Future Development, Identifying the Agenda. In Pearce, D.G., and Butler, R.W. Contemporary Issues in Tourism Development, London, Routledge.

Dann, G. 2012. Remodelling a changing language of tourism: from monologue to dialogue and trialogue. Revista de Turismo y Patrimonio Cultural. 10, 4, 59-70

Djafarova, E. and Andersen, H. (2008). The contribution of figurative devices to representation of tourism images. Journal of Vacation Marketing, 4(4), 291303. Erjavec, K. (2004). Beyond Advertising and Journalism: Hybrid Promotional News Discourse. Discourse \& Society, 15(5), 553-578.

Pragglejaz Group. (2007). MIP: A method for identifying metaphorically used words in discourse. Metaphor and Symbol, 22(1), 1-39.

Fromkin, V., Rodman, R., \& Hyams, N. (2010). An Introduction to Language. Boston: Cengage Learning.

Jaworska, A., and Pritchard, A. 2005. Discourse, Communication and Tourism. Clevedon, Channel View Publications. 
Jurnal DinamikA

Volume 1 No. 2 (2020)

E-ISSN: $2723-1410$

Website: https://jurnal.iainsalatiga.ac.id/index.php/dinamika/index

Kennedy, G. (2016). Sosial Media: Master social media marketing. North Charleston. Create Space Independent Publishing Platform

Mattiello, E. (2012). Metaphor in Tourism Discourse: Imagined worlds in English tourist texts on the web. Textus, 1(1), 67-82. 


\section{Appendices}

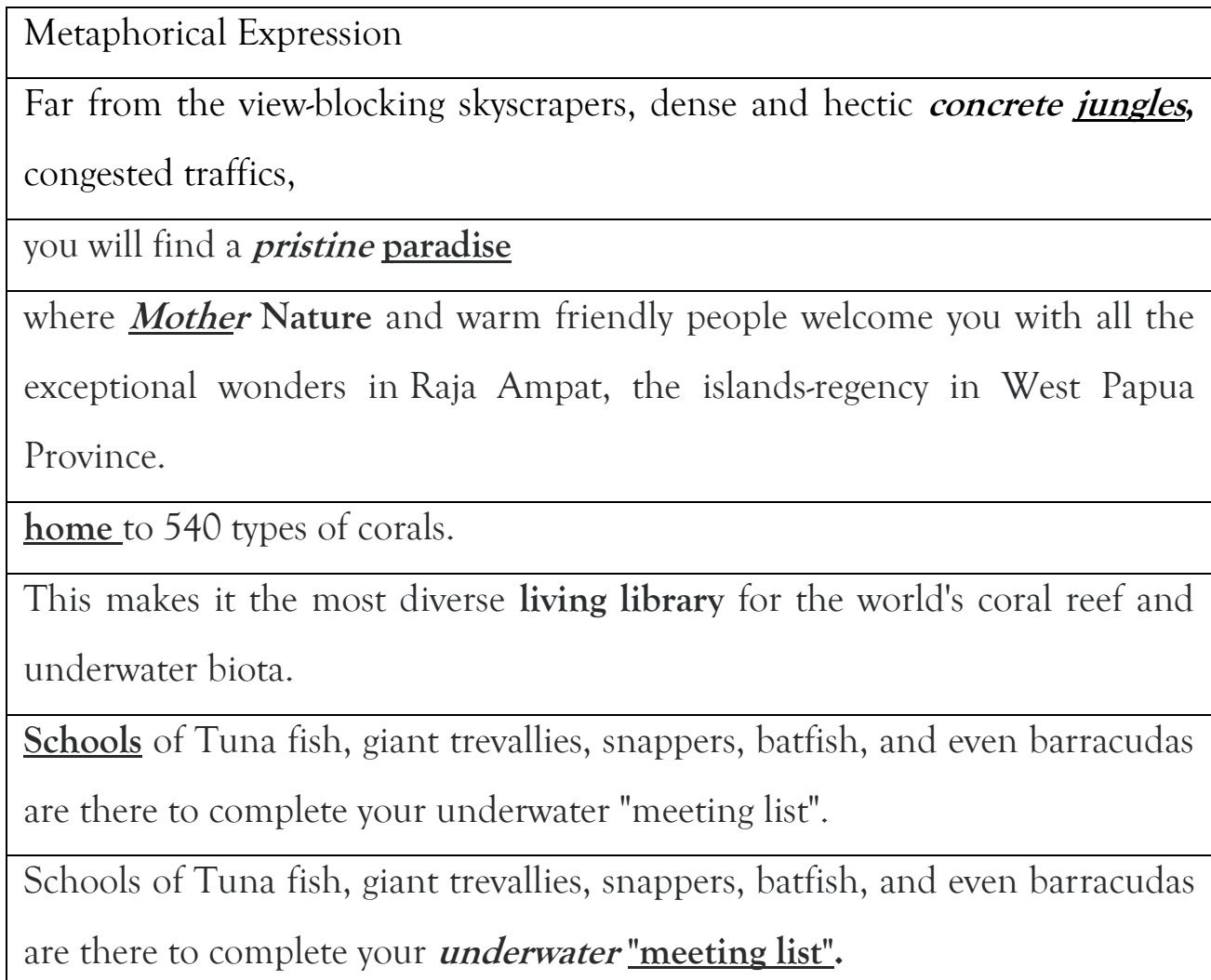

Not to mention the friendly assistant of the dugong, and a busy colleague, the turtle.

Not to mention the friendly assistant of the dugong, and a busy colleague, the turtle.

the rock islets amidst the clear blue water and bright blue sky in Piaynemo offers some of the most spectacular sceneries on the face of the earth.

the rock islets amidst the clear blue water and bright blue sky in Piaynemo offers some of the most spectacular sceneries on the face of the earth.

Mother Nature painted her finest artwork and offers a glimpse of paradise. Mother Nature painted her finest artwork and offers a glimpse of paradise. Mother Nature painted her finest artwork and offers a glimpse of paradise. Raja Ampat welcomes you to the Heaven on Earth. 


\section{Jurnal DinamikA}

Volume 1 No. 2 (2020)

E-ISSN: $2723-1410$

Website: https://jurnal.iainsalatiga.ac.id/index.php/dinamika/index

\section{Raja Ampat}

Far from the view-blocking skyscrapers, dense and hectic concrete jungles, congested traffics, flickering electric billboards, endless annoying noises, and all the nuisances of modern cities, you will find a pristine paradise where Mother Nature and warm friendly people welcome you with all the exceptional wonders in Raja Ampat, the islands-regency in West Papua Province. With all the spectacular wonders above and beyond its waters, as well as on land and amidst the thick jungles, this is truly the place where words such as beautiful, enchanting, magnificent, and fascinating get its true physical meaning.

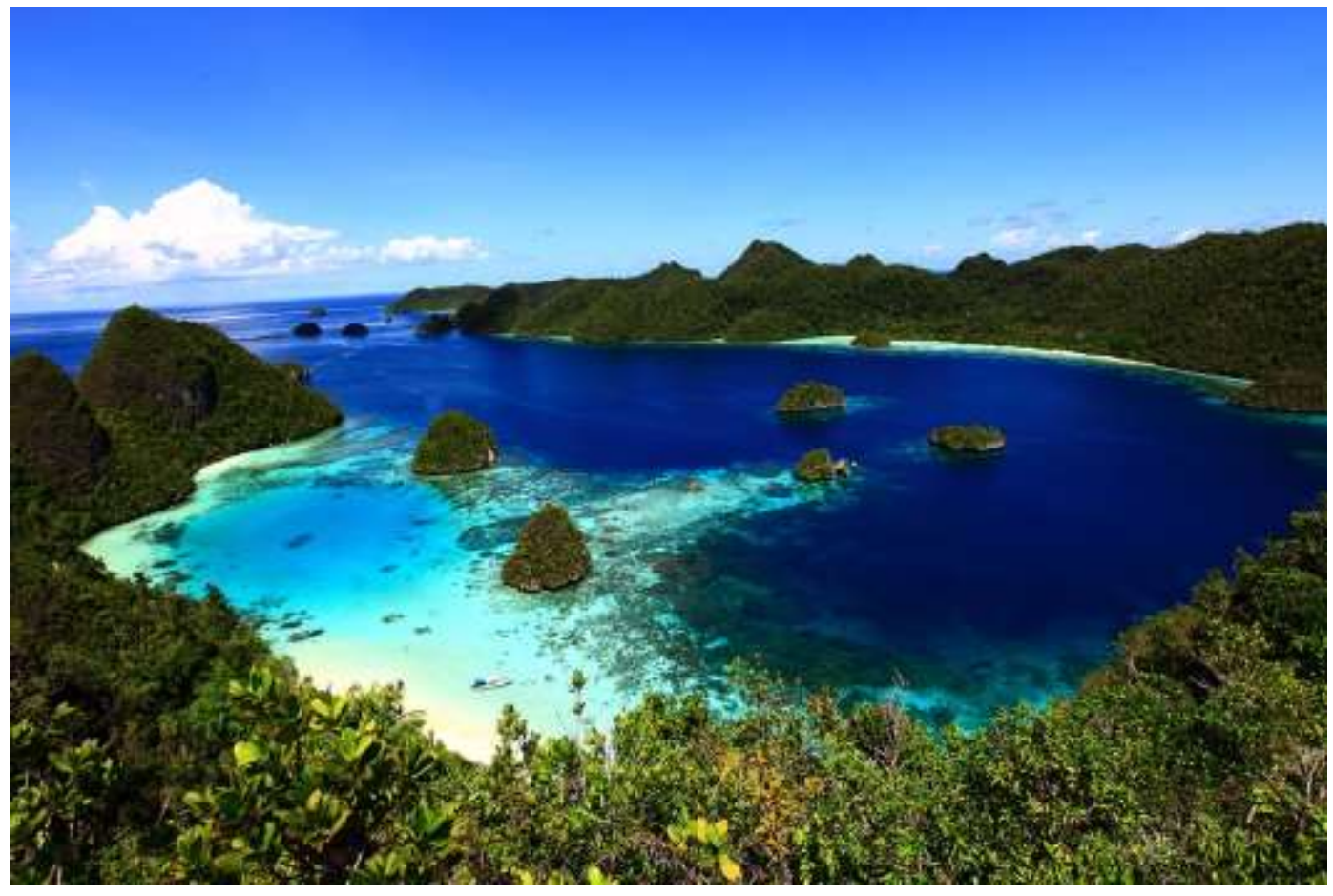

\section{The Emperor of Four}

Situated off the northwest tip of Bird's Head Peninsula on Papua, the most eastern island of the Indonesian Archipelago, Raja Ampat or literally meaning 'The Four Kings' is an archipelago comprising over 1,500 small islands, cays, and shoals surrounding the four main islands of Waigeo, Batanta, Salawati, and Misool. The 
name Raja Ampat itself is believed to derive from a legend where a woman found seven eggs, with four of them hatch and become the kings of the four main islands, while the other three became a woman, a ghost, and a stone.

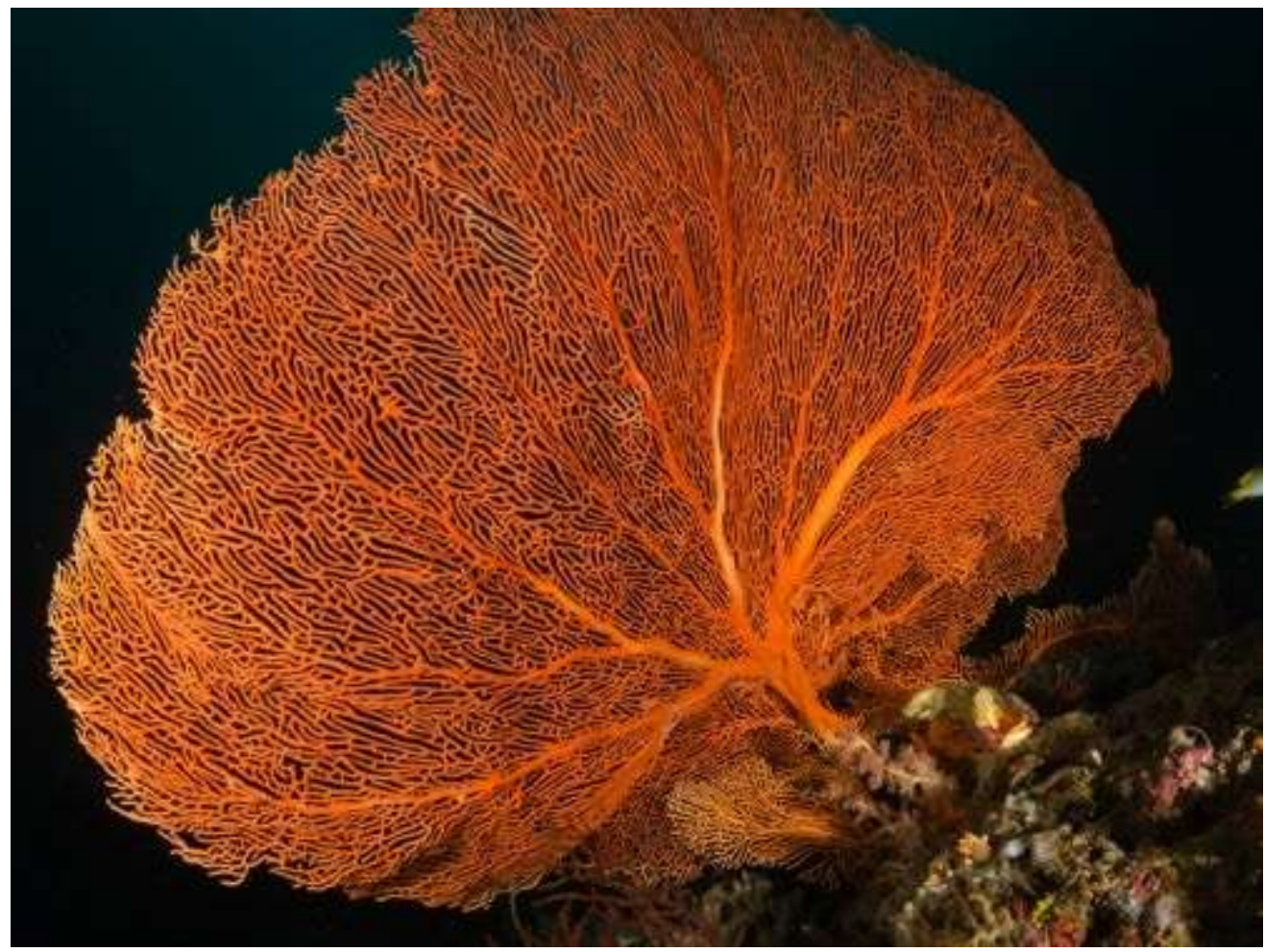

For underwater enthusiasts, Raja Ampat definitely offers some of the world's ultimate experience. The territory within the islands of the Four Kings is enormous, covering 9.8 million acres of land and sea, home to 540 types of corals, more than 1,000 types of coral fish and 700 types of mollusks. This makes it the most diverse living library for the world's coral reef and underwater biota.

\section{Video by byfieldtravel}

According to a report developed by The Nature Conservancy and Conservation International, around $75 \%$ of the world's species live here! Raja Ampat's sheer numbers and diversity of marine life and its huge pristine coral reef systems are a scuba dream come true - and a fantastic site for snorkelers too. 


\section{Jurnal DinamikA}

Volume 1 No. 2 (2020)

E-ISSN: 2723-1410

Website: https://jurnal.iainsalatiga.ac.id/index.php/dinamika/index

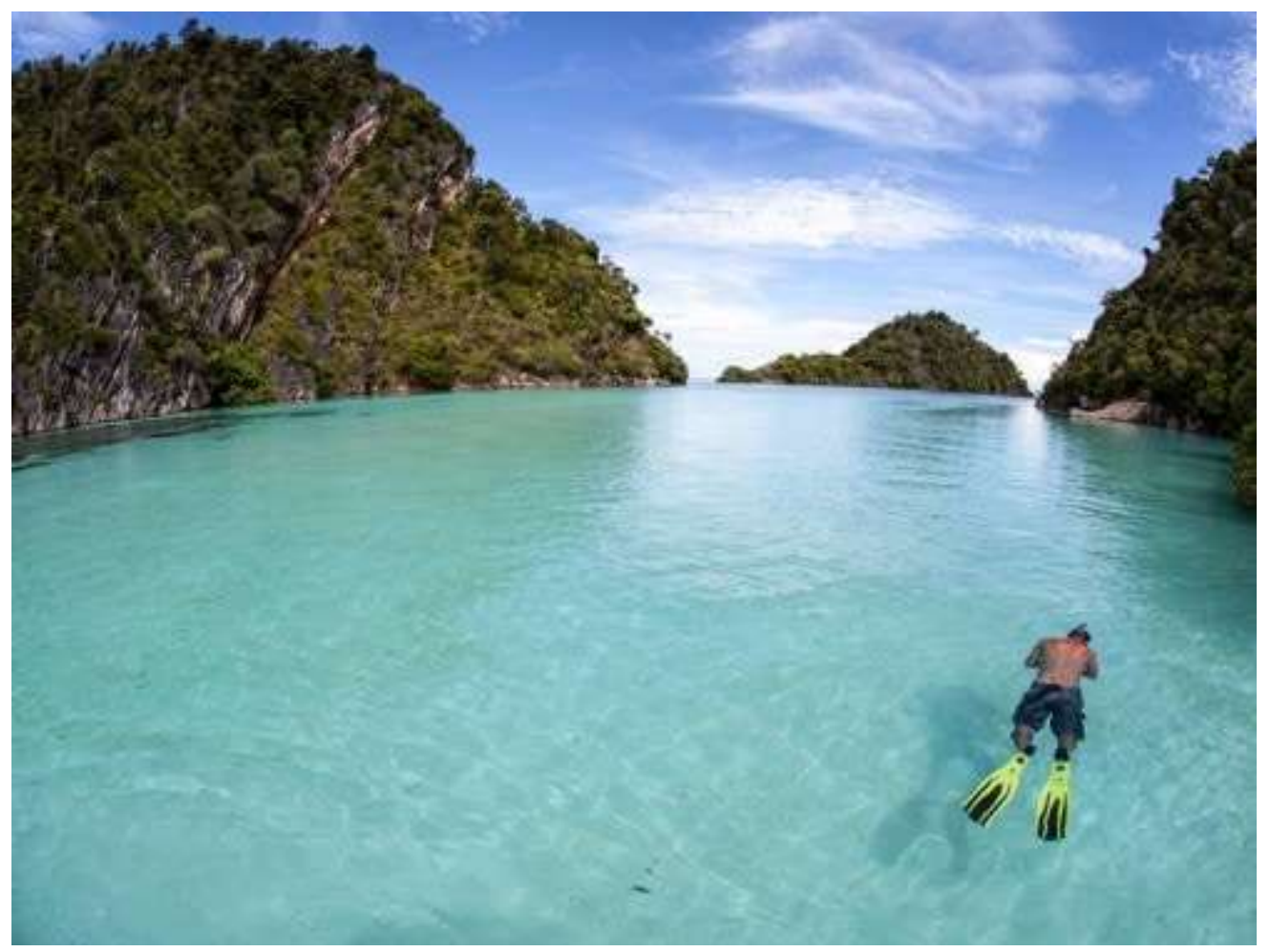

As you embark on your dive here, the phrase "Attention to detail" takes on new meaning as pigmy seahorses swim around your fingers. Manta Rays and wobbegongs will glide right by you. Schools of Tuna fish, giant trevallies, snappers, batfish, and even barracudas are there to complete your underwater "meeting list". Not to mention the friendly assistant of the dugong, and a busy colleague, the turtle. Down at the sea floors, giant sea clams measuring to over one meter in length truly offers one of kind close encounter sensation. 


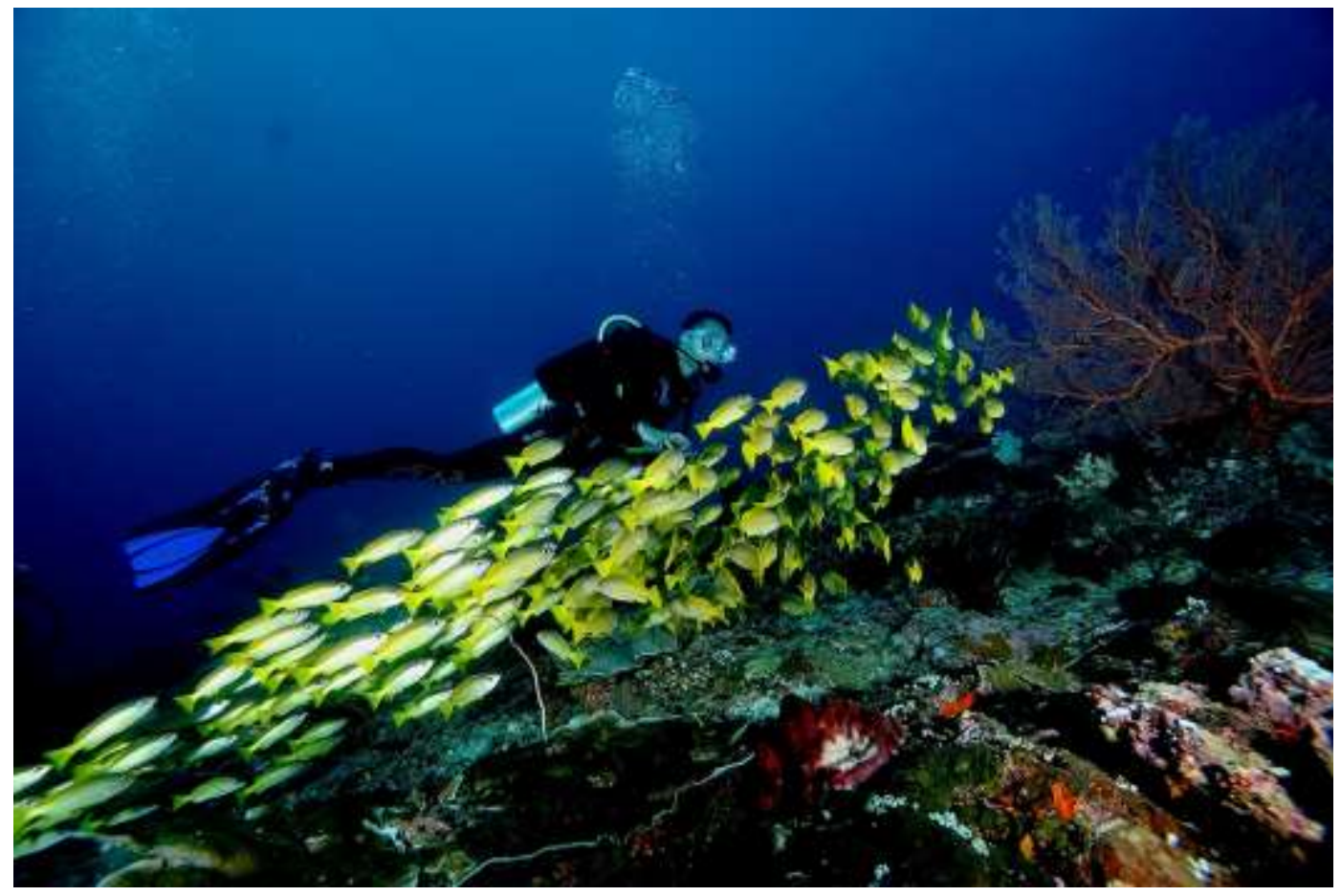

Obviously, there are a lot of diving and snorkeling spots to choose from in these vast waters. Among these are at the Kabui Passage (the very narrow passage between Waigeo and Gam Island crossed by the renowned British explorer, Alfred Russell Wallace in 1860), around the Arborek Island's Dock, Sawandarek, Yenbuba, Friwen Wall, and many-many more. 


\section{Jurnal DinamikA}

Volume 1 No. 2 (2020)

E-ISSN: $2723-1410$

Website: https://jurnal.iainsalatiga.ac.id/index.php/dinamika/index

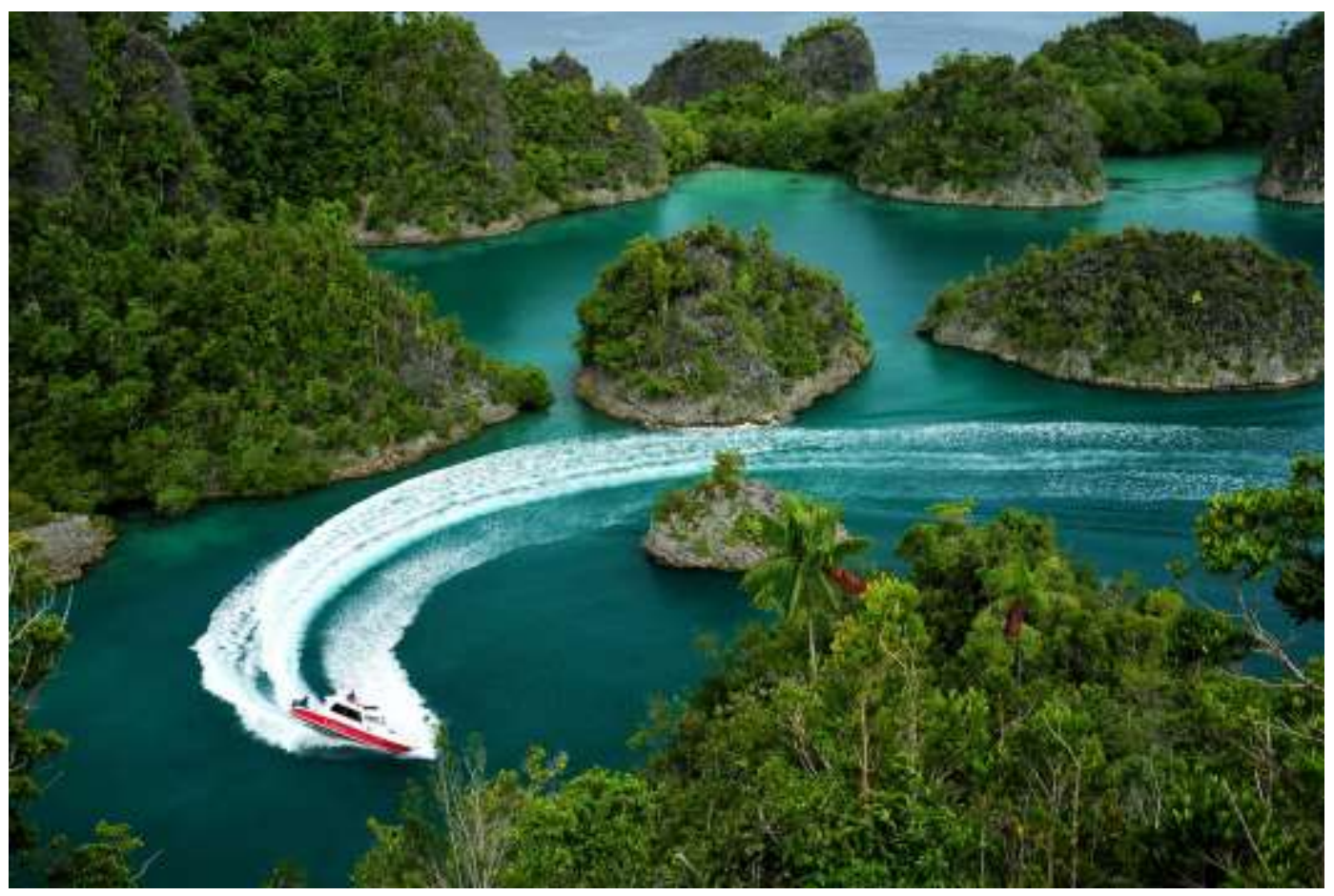

While its underwater splendors are beyond exceptional, the landscape above the surface is equally breathtaking. As if it was carefully designed and placed with such aesthetic, the rock islets amidst the clear blue water and bright blue sky in Piaynemo offers some of the most spectacular sceneries on the face of the earth. Looking down from the top of the hill, it almost seems that Mother Nature painted her finest artwork and offers a glimpse of paradise. Further at Wayag Island, you will also find an amazing rock islets formation in an even bigger scale. 


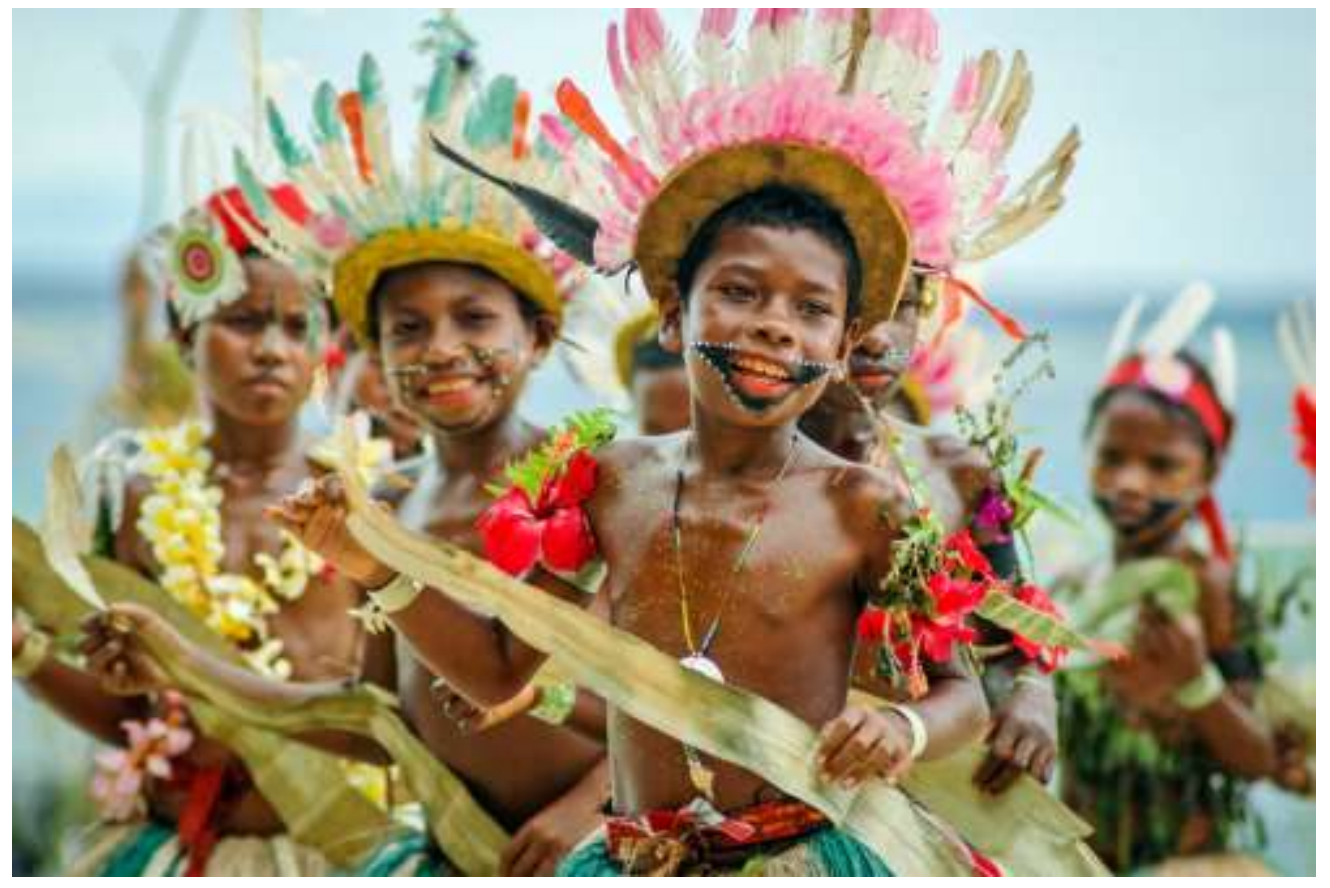

The incredible wildlife of Raja Ampat does not stop underwater. Amidst the many thick jungles within the islands, one can still find various bird species including the spectacular Cendrawasih or the bird of Paradise. There is also an endemic species of cuscus, the Waigeou cuscus or Waigeou spotted cuscus (Spilocuscus papuensis) which is a species of marsupial in the family Phalangeridae. 


\section{Jurnal DinamikA}

Volume 1 No. 2 (2020)

E-ISSN: $2723-1410$

Website: https://jurnal.iainsalatiga.ac.id/index.php/dinamika/index

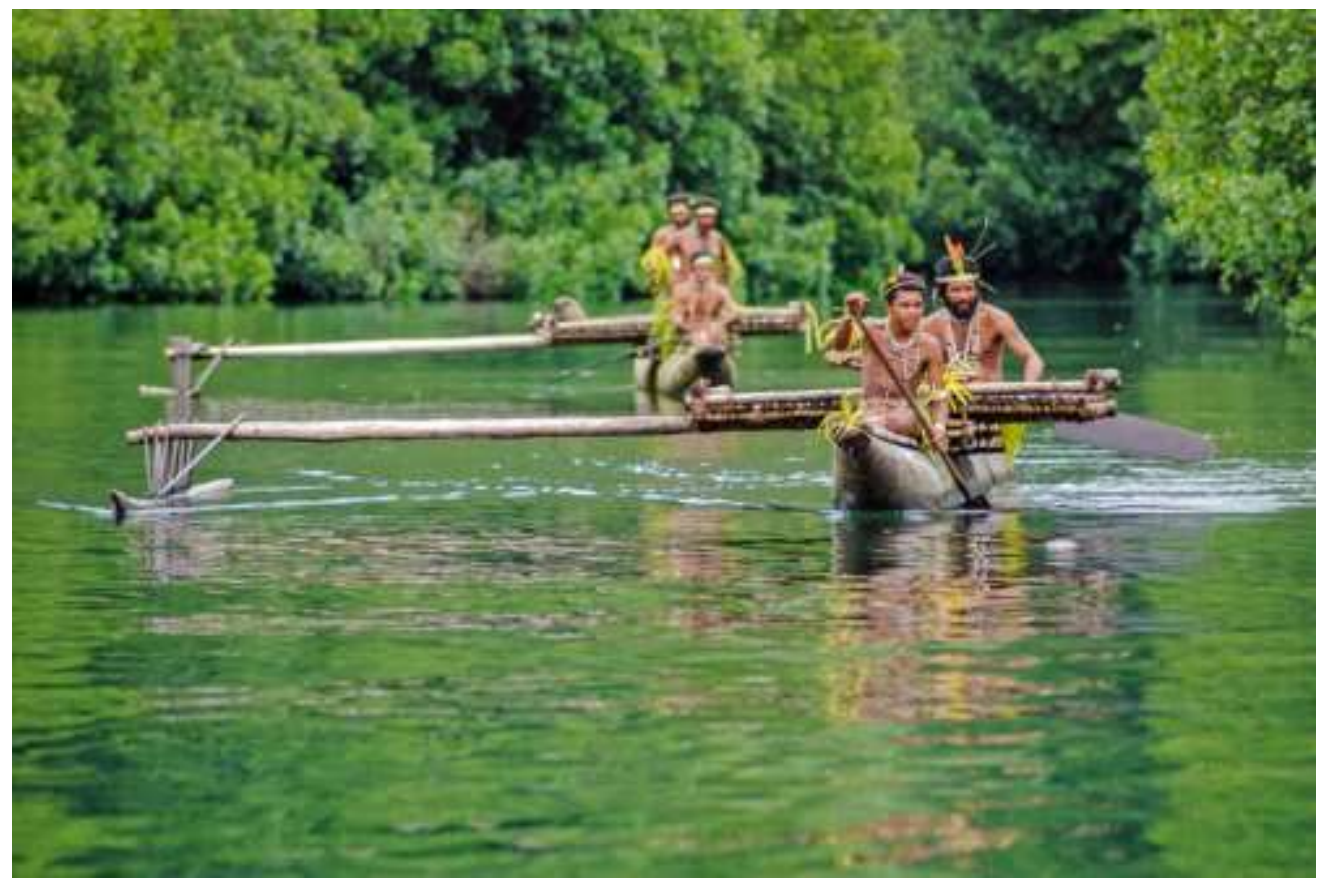

\section{The Local Ambience}

Aside from its endless fascinating natural attractions, Raja Ampat also offers the distinct hospitality of the Papuan. At the Arborek Tourism Village, you can stay at a number of homestays and mingle with the locals whilst observing their daily life and unique traditions. When a group of tourists arrived, they usually perform a traditional welcome dance right at the dock and entertained the 'guests' with various Papuan folk songs.

With all its spectacular wonders inland, on the shore, and beyond the waters, and distinct serene ambiance that you rarely find anywhere else on earth, Raja Ampat truly offers the ultimate experience ones can only dream of.

So, whether you are an avid diver, occasional snorkeler, or just someone who appreciated the beauty in every sense, Raja Ampat welcomes you to the Heaven on Earth. 